\section{Japanese bid riles Congress}

\section{Washington}

Evoking one of the most sordid political scandals in American history, Senator Albert Gore (Democrat, Tennessee) last week attacked US officials for permitting a Japanese takeover of a US company tied to the government-subsidized Sematech electronics consortium. The twisted tale behind the planned sale - which involved White House intervention and the creation of a complicated systems of checks and balances to insure that the Japanese are not able to obtain Sematech technology - threatens to become an "electronic Teapot Dome", Gore' claimed, with characteristic hyperbole, in a raucous hearing of the Commerce, Science and Transportation Committee.

At the centre of the controversy is SemiGas Systems, Inc., a small Californiabased company that provides very highly purified gas for the production of semiconductor chips. Sematech officials claim that Semi-Gas's technology is two years ahead of any competitor. At least five of the company's key technologies have been developed with the cooperation of Sematech, the US government/industry semiconductor consortium formed to counter Japanese domination of the global semiconductor market.

In April, the Japanese chemicals company Nippon Sanso offered Semi-Gas's parent company, Hercules, Inc., \$23 million for the company. Although SemiGas officials strongly opposed the sale, they have so far been unable to raise enough money to buy the company themselves. Last week, an interagency government panel - created to prevent loss of key US technology in just this sort of takeover - approved the sale after recommending an extraordinarily complicated system of protective measures to isolate Sematech technology from Japanese industry.

President George Bush has agreed to the panel's recommendation. Although the Justice Department is still reviewing the antitrust implications of the sale which could give Nippon Sanso as much as 70 per cent of the world-wide high-purity gas market - Sematech officials give the agreement even odds of approval.

After Gore's hearing last week, those odds may have to be recalculated. The senator claimed that the deal raises the possibility that, with as little as $\$ 23$ million, a Japanese company may have bought its way into the United States' first-line defence against Japanese domination of the electronics market. Sematech was jointly formed by the US defence department and 14 industrial partners expressly to develop "precompetitive" semiconductor technology that could buoy a US industry faced with
Japanese competitors of apparently unbeatable efficiency.

Although Semi-Gas is not one of Sematech's 14 industrial partners, its technicians work in Sematech's laboratories and much of its technology has been developed with the (taxpayer-subsidized) help of Sematech.

"It's an incredible list of jewels that we are - thanks to President Bush - turning

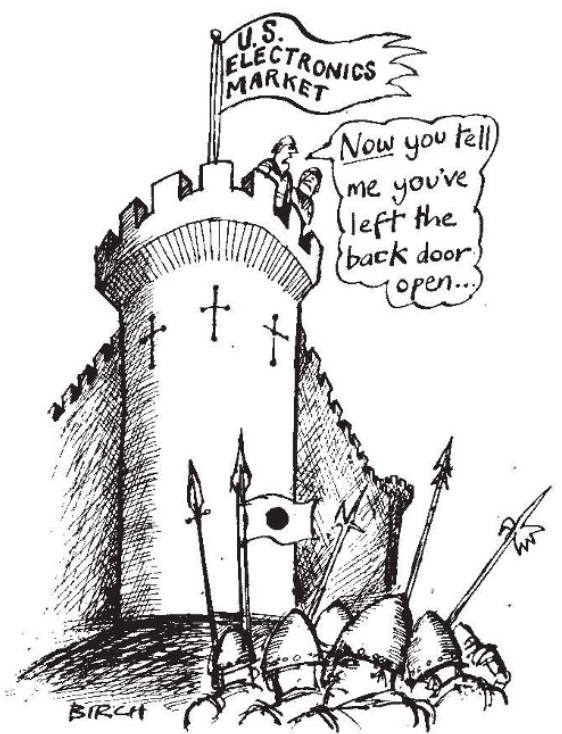

over to the Japanese", Gore said. (White House officials dispute this, saying that at least six other companies have technology on a par with that of Semi-Gas, according to Robert Park, Washington director of the American Physical Society). Sema-
NATURAL HISTORY MUSEUM

\section{London}

THE management of the Natural History Museum appears to be backing down slightly from its much-criticized intention to declare some research staff redundant. The NHM's corporate plan provoked unprecedented criticism ealier this year when it declared that one researcher in six would have to be dismissed in order to restructure the museum financially ( $\mathrm{Na}$ ture 344, 805; 26 April 1990; 345, 655; 21 June 1990). But three senior researchers faced with immediate dismissal have now been reprieved: archaeozoologist Juliet Clutton-Brock will be allowed to stay until her official retirement, three years hence palaeobotanist Chris Hill has been offered a three-year fellowship; and the palaeontologist Alan Gentry has been given an extension of a year.

These latest moves risk being seen only as a token gesture to appease the scientific community: at the same time as they were announced NHM director Neil Chalmers reaffirmed his present inclination to sup- tech officials estimate that, if Semi-Gas were to be sold to a Japanese concern, finding a replacement or otherwise protecting Sematech technology would delay current projects by at least six months. Given that Sematech's annual budget is about $\$ 200$ million, such a hiatus could cost the consortium as much as $\$ 100$ million, they claim.

To prevent Nippon Sanso from gaining access to Sematech's industrial secreis through Semi-Gas, the US Committee on Foreign Investments in the US (CFIUS) is said to have negotiated a complex layering scheme to isolate those Semi-Gas employees who work at Sematech. According to press accounts, the Semi-Gas technicians will report to a special middleman company (controlled by US citizens, including at least one from Sematech), rather than to Nippon Sanso or Semi-Gas directly. Semi-Gas would also be required to protect Sematech documents in a "secure area".

However, Sematech officials said late last week that they had still not heard from CFIUS, and, in fact, had only learned of a negotiated settlement by reading the Wall Street Journal.

Robert White, undersecretary for technology at the Department of Commerce, told Gore that although he had been consulted in the deliberations, he did not know of the confidentiality pact. $\mathrm{He}$ pointed out, however, that the act under which the president could countermand such a takeover demands that a rejected bid demonstrate "very clear evidence that it endangers national security". In the case of Semi-Gas, no such evidence has been shown, he said.

Christopher Anderson

\title{
Reprieves for some senior researchers
}

port the commercial exploitation of Museum expertise rather than the development of its "strategic" research. In the latest issue of Museums Journal (August, 1990), he says "what most of the world wants from us are good advisory services and not good research". But just 18 months ago, support for taxonomic research seemed to be at the forefront of his policies (Nature 336, 707; 22/29 December 1988).

Chalmers' U-turn is also evident in an internal memorandum circulated in the Museum's Department of Public Services (the arm of the NHM responsible for exhibitions). In the confidential memo, leaked to Nature, the Director makes plain that Museum scientists will be required to engage in "corporate" activities. A senior Museum scientist (who declined to be named) said that "corporate activities" account for 5 per cent of Museum researchers' time according to their new job descriptions but nobody seems to know what these activities involve. Henry Gee 